\title{
Indirect effects of excessive deer browsing through understory vegetation on stream insect assemblages
}

\section{$\operatorname{AUTHOR}(\mathrm{S}):$}

Sakai, Masaru; Natuhara, Yosihiro; Imanishi, Ayumi; Imai, Kensuke; Kato, Makoto

\section{CITATION:}

Sakai, Masaru ... [et al]. Indirect effects of excessive deer browsing through understory vegetation on stream insect assemblages. Population Ecology 2012, 54(1): 65-74

\section{ISSUE DATE:}

2012-01

URL:

http://hdl.handle.net/2433/152318

\section{RIGHT:}

The final publication is available at www.springerlink.com; この論文は 出版社版でありません。引用の際には出版社版をご確認ご利用くださ $\iota_{\circ}$; This is not the published version. Please cite only the published version. 
1 Title: Indirect effects of excessive deer browsing through understory vegetation on

2 stream insect assemblages

3

4 Names of authors: Masaru Sakai, Yosihiro Natuhara, Ayumi Imanishi, Kensuke Imai,

5 Makoto Kato

6 Affiliations:

7 Masaru Sakai, Yosihiro Natuhara, Ayumi Imanishi, Makoto Kato: Graduate School of

8 Global Environmental Studies, Kyoto University

9 Kensuke Imai: Department of Human Environments and Architectural Design, Osaka

10 University of Human Sciences

11

12 Information of corresponding author (Masaru Sakai):

13 Address: Yoshida-honmachi, Sakyo-ku, Kyoto, 606-8501, JAPAN

14 E-mail address: $\underline{\text { m.sakai@fw3.ecs.kyoto-u.ac.jp }}$

15 Telephone / Fax number: +81-75-753-6845 / +81-75-753-6694

16

17 Number of text pages: 23

18 Number of tables: 4

19 Number of figures: 6

20 Number of Electronic Supplementary Materials: 1 
23 Abstract

25 Over the past decade, the abundance of sika deer has rapidly increased around Japan.

26 Previous studies have showed overabundance of deer causes drastic reduction of forest

27 understory vegetation, leading excessive soil erosion. However, no study has

28 investigated the effects of excessive deer browsing on aquatic insect assemblages via

29 sediment runoff. These effects are important to understand whether the terrestrial

30 alteration by deer influences aquatic ecosystems. In a primary deciduous forest

31 catchment in Ashiu, Kyoto, a deer exclusion fence has been in place since 2006. We

32 compared forest floor cover, overland flow, stream environment, and aquatic insect

33 assemblages in first-order streams and catchments inside and outside of the deer-

34 exclosure from May-2008 to April-2009. The floor inside the deer-exclosure catchment

35 was covered by lush understory vegetation, whereas outside was almost bare. The overland flow runoff rate at midslope and the dominancy of fine sediment deposition in

37 the streambed were higher outside than inside. Among aquatic insects, burrowers,

38 which are tolerant against fine sediment deposition, were significantly more abundant

39 outside than inside, whereas clingers exhibited the opposite patterns. Collector-

40 gatherers, which feed on fine detritus, were significantly more abundant outside than inside. Meanwhile, filterers were more abundant inside. The Simpson's diversity index of the aquatic insect assemblages was higher inside than outside. These results suggest

43 that the demise of understory vegetation due to excessive deer browsing has indirectly

44 caused changes in the aquatic insect assemblages of this catchment via increased

45 sediment runoff and subsequent sandy sedimentation of the streambed. 
$47 \quad$ Key words

48

Burrowers $\cdot$ Clingers $\cdot$ Diversity $\cdot$ Sedimentation $\cdot$ Soil erosion

\section{Introduction}

52

53 Deer populations are increasing in many countries due to various factors such as the

54 extinction of predators, moderation of the winter climate, decreased hunter populations, and strengthening of game laws (Côté et al. 2004). Increased deer populations can cause reductions in preferred plants, increases in deer-resistant plants, and declines in plant diversity (e.g., Fuller and Gill 2001; Gill and Beardall 2001; Rooney 2001; Horsley et al. 2003; Casabon and Pothier 2008). Population of sika deer (Cervus nippon

Temminck) has increased in many places of Japan since 1980s (Miura and Tokida 2008). Excessive sika deer browsing directly affects plant communities by denuding forest floor vegetation (Takatsuki and Gorai 1994), stripping tree bark and causing tree death (Akashi and Nakashizuka 1999), damaging shrubby bamboo stands (Yokoyama and Shibata 1998), seed predation (Asada and Ochiai 1996), and inhibiting tree regeneration (Nomiya et al. 2003).

Excessive deer browsing can also lead to the devastation of natural vegetation and the alteration of soils. For example, denuded understory vegetation causes runoff of soil

67 and litter (Furusawa et al. 2003) as well as changes in the physical properties of forest

68 soil (Miyashita et al. 2008; Yanagi et al. 2008). Understory vegetation protects soil from

69 becoming encrusted by the impact of raindrops; thus, understory vegetation sustains the 
70 high infiltration capacity of forest soil (Onda and Yukawa 1994; Gomi et al. 2008).

71 Consequently, the denudation of the understory accelerates the discharge of infiltration excess (Hortonian) overland flow, in turn causing soil erosion (Horton 1945; Sidle et al. 2007; Gomi et al. 2008). Several previous studies have demonstrated that such soil erosion occurs in areas where understory vegetation has been denuded by excessive deer browsing (Miyashita et al. 2008; Wakahara et al. 2008).

Small catchments, which contain first-order streams, are located at the top, precipitous edges of rivers, and are the most active geomorphic development areas in river basins because of erosion and landslides. Therefore, active sediment supply originating from terrestrial slopes in these catchments greatly influences the environmental and ecological systems of first-order streams. Sediment runoff alters not only turbidity but also stream substrates, both of which may affect stream communities (e.g., Rabení and Minshall 1977; Minshall 1988). In headwater systems, riparian forests also influence aquatic insect communities in streams by controlling solar radiation and

84 temperature (Richardson and Danehy 2007); providing litter and cladoptosis, which are sources of food and case materials; and creating multiple habitats through the production of woody debris (Richardson and Danehy 2007). Aquatic insects represent

87 various life form types and functional feeding groups, as they have adapted to diverse stream microhabitats and food resources (Takemon 2005; Merritt et al. 2008). These

89 insects play important roles in sustaining river ecosystems, functioning as decomposers,

90 primary consumers, prey for fish and other predators, and agents transporting organic

91 matter from stream to terrestrial ecosystems (Covich et al. 1999). Because aquatic insect

92 communities are vulnerable to various environmental changes, the status of these

93 organisms is often used as an index of river health (e.g., Robinson and Minshall 1986; 
94 Zweig and Rabeni 2001; Rainbow 2002; Heino et al. 2003; Matthaei et al. 2006;

95 Yoshimura 2007).

96 As noted above, excessive deer browsing accelerates soil erosion in small forested

97 catchments. In this study, we examined whether such consequences of deer browsing

98 affect aquatic insect communities. To test this question, we compared forest floor cover,

99 overland flow, stream environment, and aquatic insect assemblages inside and outside

100 of a deer exclosure in a cool-temperate primary forest in Japan. We then discuss the

101 effects of excessive deer browsing on aquatic insect assemblages in first-order streams.

102

103 Materials and methods

104

105 Study site

106

107 This study was conducted in the first-order streams of the Yura River at the Ashiu

108 Forest Research Station, Field Science Education and Research Center, Kyoto

109 University $\left(35^{\circ} 20^{\prime} \mathrm{N}, 135^{\circ} 45^{\prime} \mathrm{E}\right.$; Fig. 1). Average annual precipitation and temperature

110 were $2,298 \mathrm{~mm}$ and $11.9^{\circ} \mathrm{C}$, respectively, from 1976 to 2005 at the Ashiu Research

111 Station. Maximum snow depth in winter exceeds over $2 \mathrm{~m}$ around the study site, and the

112 ground is covered with snow from mid-December to early April. The geological

113 components of the area are sandstone, mudstone, and shale of the Tanba Belt of the

114 Mesozoic. Most of the soil is brown forest soil.

115 Excessive deer browsing has become a serious problem at the study site since the late

116 1990s (Tanaka et al. 2008) and has caused drastic decreases in the abundance and

117 diversity of understory plants (Kato and Okuyama 2004). Resent minimum-maximum 
118 population density of deer in the study site, estimated by block count during two days in

119 December, were; $2.30-4.21$ (2006), 0.00-5.30 (2007), 1.15-5.75 (2008), 0.00-5.75

120 (2009), 4.60-13.80 indv. / km² (2010) (A. Takayanagi, unpublished data). A catchment

121 in the natural deciduous forest (area: 1.15 ha) has been fenced to exclude deer since

1222006 (Fig. 1). The 2.5-m-high fence is constructed of poles and nets. No deer had

123 invaded inside the fence during the study period according to monthly fence

124 maintenance and visual survey of deer browsing scar along the fence (A. Takayanagi,

125 unpublished data). Understory vegetation in the exclosure catchment had recovered well

126 by 2008 , whereas vegetation outside the exclosure has remained almost denuded.

127 Outside the deer exclosure in a neighboring valley, we selected a control catchment

128 (area: 1.66 ha) (Fig. 1). The plant community structures at the exclosure and control

129 catchments had been very similar at the start of deer exclusion (Sakaguchi et al. 2008),

130 and water temperature and quality in the streams at each catchment were almost same

131 (Table 1 and Fukushima and Tokuchi 2008). To clarify the indirect effects of excessive

132 deer browsing on aquatic insect assemblages as much as possible, the selected two

133 catchments were adjoining and have topographically similar streams in the same way of

134 the antecedent control experiments (e.g., Allan 1982; Christopher and Minshall 1986;

135 Matthaei et al. 2006). We compared forest floor cover, overland flow, environmental

136 stream characteristics, light conditions, periphyton abundance, and aquatic insect

137 assemblages between the exclosure and control catchments (EC and CC, respectively).

138 The first-order streams in each catchment contain permanent water. Both catchments

139 are covered by primary cool-temperate deciduous forests dominated by Aesculus

140 turbinate Blume, Quercus crispula Blume, Fagus crenata Blume, Clethra barbinervis 
141 Sieb. et Zucc., Acer palmatum subsp. matsumurae (Koidz) Ogata, Pterocarya rhoifolia

142 Sieb. et Zucc., and Cryptomeria japonica var. radicans Nakai.

144 Forest floor cover and overland flow

146 One belt transect ( $1 \mathrm{~m}$ wide) from the valley floor to $30 \mathrm{~m}$ up the upper slope was

147 established on the left bank of each catchment. The belt transect, which was oriented to

148 include representative vegetation of each catchment, was divided into fifteen $1 \times 2 \mathrm{~m}$

149 plots, and coverage of understory vegetation in every plot was recorded by visual

150 observation. Then, abundance and number of understory plant species in the belt

151 transect was also recorded. The survey was conducted in June and August 2008.

152 To evaluate the quantity of litter in each catchment, we collected litter in four randomly selected quadrats along the downhill slopes of each catchment in August and

154 November 2009. Collected litter was dried at $60^{\circ} \mathrm{C}$ for $24 \mathrm{~h}$ and then weighed.

155 Runoff plots $(0.5 \times 2.0 \mathrm{~m})$ were established at the midslopes of each catchment.

156 Plastic borders were inserted about $5 \mathrm{~cm}$ into the soil along all sides of the plots, and a

157 trough was inserted several centimeters into the soil (parallel to the slope direction) to

158 collect storm runoff. Runoff from these plots was routed to a rain gauge (Davis

159 Instruments, Rain Collector II) to estimate discharge per 5 min (Fig. 1). Precipitation

160 was measured by a rain gauge (Davis Instruments, Rain Collector II) situated in an open

161 area (Fig. 1). Overland flow and precipitation were monitored from June to November

162 2009. We defined rainfall event as rainfalls whose total precipitations were more than

$16310 \mathrm{~mm}$ and there is no rain during at least $3 \mathrm{~h}$ before and after the rainfall. In addition,

164 we classified rainfall event into three types (1) intermissive, (2) continual and (3) one- 
165 peak rainfall events. If a rainfall event has over 15-min-intermission of rainfall more

166 than four times, we regard the rainfall event as intermissive rainfall event. If a rainfall

167 event continues with no intermission above noted, and has more than one peak, the

168 rainfall event is regarded as continual rainfall event. If the rainfall has only one peak,

169 the rainfall is regarded as one-peak rainfall event.

170

171 Aquatic insects

172

173 Four quadrats were set with a surber net $(25 \times 25 \mathrm{~cm}, 0.5-\mathrm{mm}-\mathrm{mesh}$ sieve $)$ in the

174 streams in each catchment. Each sampling point was located over at least a 50-cm-wide

175 stretch of the streams, at locations where some very coarse gravel was distributed.

176 Sediments with benthic animals in each quadrat were collected into the surber net, and

177 as many animals as possible were collected after being placed into white vats.

178 Collections were conducted every month from May to November 2008 and in April

179 2009. Collected animals were preserved immediately in 70\% ethanol. Aquatic insects

180 were separated out and classified using a stereomicroscope (Nikon SMZ800) following

181 Kawai and Tanida (2005) and Merritt et al. (2008). Because all identified taxa were not

182 classified to species, the number of species was underestimated. Identified aquatic

183 insects were sorted by life form type (swimmers, crawlers, clingers, or burrowers) and

184 functional feeding group (shredders, filterers, collector-gatherers, predators, or grazers)

185 based on Takemon (2005) and Merritt et al. (2008).

186 In general, aquatic insect distribution is ultimately structured by physical-chemical

187 tolerance of individuals in the population (Cummins et al. 2008), and fecundity of

188 aquatic insects is precisely determined by temperature (Vannote and Sweeny 1980; 
189 Rader and Ward 1990). Individuals of aquatic insects are distributed following their

190 optimal temperature regime along a thermal gradient related to altitude. Therefore, we

191 regarded aquatic insect assemblages in the EC and CC before the start of deer exclusion

192 in 2006 as very similar structures because of their physical (Table 1 and Fig. 1),

193 chemical (Fukushima and Tokuchi 2008) and thermal similarities (Table 1).

194

195 Environmental characteristics of the streams

196

197 The water depth in each quadrat was calculated by averaging the depths at six points in

198 each quadrat. Current velocity at the center of each quadrat was calculated by averaging

199 three averages of repeated 5-s measurements using a current meter (Kenek, VE10).

200 We used visual estimation and grain size test to evaluate streambed characteristics.

201 To evaluate the stream substrate, photographs were taken from $50 \mathrm{~cm}$ above the

202 streambed in each quadrat. The proportion of fine sediment in each quadrat was

203 calculated using Adobe Photoshop Elements, version 5.0. Randomly shoveled three

$2041000 \mathrm{ml}$ stream substrates were sieved into eleven grain sizes: $63,31.5,16,8,4,2,1$,

$2050.5,0.25,0.125$, and $0.063 \mathrm{~mm}$, and dried at $105^{\circ} \mathrm{C}$ for $24 \mathrm{~h}$ and weighed. These

206 surveys were conducted in August, September, and October 2008 except grain size test,

207 which was conducted in December 2010. We monitored the water temperature in the

208 terminal point of each catchment from April 2010 to November 2010 per 5 min using

209 thermometer (Trutrack, SE-TR/WT500).

210

211 Light conditions 
213 Hemispherical photographs were taken around the quadrats in each catchment in August

2142008 and April 2009 to determine the light conditions above each streambed. The first

215 photographs were taken in the terminal area of each catchment, and the last five were

216 taken about $6 \mathrm{~m}$ from the previous point. Photographs were taken with a digital camera

217 (Nikon E995) equipped with a fish-eye lens (Nikon FC-E8) that was fixed horizontally

218 at $1 \mathrm{~m}$ above the streambed. Relative solar radiation from May to October 2008 was

219 calculated as a measure of light conditions in the growing season using photographs

220 taken in August. Values from November 2008 to April 2009 were calculated as light

221 conditions in the fall using photographs taken in April. Solar radiation was estimated

222 from photographs using Gap Light Analyzer version 2.0. Magnetic north was set at a

223 declination of $7.20^{\circ}$ west. The radiation component was set as the default value.

225

Periphyton

226

227 Four submerged rocks were randomly collected from around the quadrats in each

228 catchment in August, September, and October 2008. Periphyton was collected by

229 brushing $4 \mathrm{~cm}^{2}$ of the upper surface of each rock and filtering the water through glass

230 microfiber filters (Whatman GF/F). These samples were ground in $90 \%$ acetone and

231 then centrifugally separated (Hitachi CF16RXII) after being dried and frozen. The

232 absorbance of the periphyton samples was measured at 750, 664, 647, and $630 \mathrm{~nm}$

233 (Hitachi U-1800). The amount of chlorophyll $a$ was calculated by substituting the

234 measured values into the formula of Jeffrey and Humphrey (1975).

235

236 Statistical analyses 
$238 T$ tests were used to determine the differences between the EC and CC in the coverage

239 of understory vegetation, amount of litter, water temperature, water depth, current

240 velocity, proportion of fine sediment, relative solar radiation, and periphyton

241 abundance. The values of coverage of understory vegetation and proportion of fine

242 sediment were arcsine-transformed to normalize distributions and standardize variance

243 structures.

244 To test for differences in aquatic insect variables between the EC and CC, a two-way

245 analysis of variance (ANOVA) was performed using streams $(n=2)$ and sampling

246 month $(n=8)$ as factors. For ANOVAs with significant effects, multiple mean

247 comparisons were made using Tukey's test. Abundance data were log-transformed to

248 normalize distributions and standardize variance structures following Yamamura (1999)

249 prior to statistical analyses.

250

$251 \quad$ Results

252

253

Forest floor cover and overland flow

254

255 Vegetation cover on the hillslope was higher in the exclosure catchment (EC) than in

256 the control catchment (CC) (Table 1 and Fig. 2), where understory vegetation was

257 almost denuded and the soil was exposed in a large area (Fig. 2). The number of

258 understory plant species was higher in the EC ( 82 species) than in the CC (31 species).

259 Preferred plant species for deer were more abundant in the EC than in the CC whereas

260 unpreferred species were commonly distributed both in the catchments (S1 in the 
261 Electronic Supplementary Material, ESM). The abundances of some unpreferred plant species such as Dennstaedtia scabra (Wall. ex. Hook.) Moore and Shortia uniflora var. kantoensis Yamazaki were higher in the $\mathrm{CC}$ than in the EC (S1 in the ESM). There were 16 intermissive, 12 continual and 8 one-peak rainfall events during the monitoring period. Total runoff of overland flow during the representative rainfall event was lower in the EC compared to the CC for all three types of rainfall events (Fig. 3). In particular, the overland flow hydrographs at the CC were sharply peaked during intermissive and one-peak rainfall events. Runoff rate of overland flow during entire of the motoring period (i.e., runoff / precipitation) was $4.10 \%$ and $1.55 \%$ in the $\mathrm{CC}$ and $\mathrm{EC}$ respectively. Thus, overland flow discharge was about 2.65 times greater in the $\mathrm{CC}$ than in the EC.

Environmental characteristics of the streams

274 Water depth, current velocity, and relative solar radiation were relatively similar

275 between the EC and CC (Table 1). However, the proportion of fine sediment in the

276 streambed was significantly higher in the $\mathrm{CC}$ than in the EC (Table 1), and the grain

277 size of particles was biased to small in the CC in comparison with that the EC (Fig. 4).

278 The effective grain size $\left(\mathrm{D}_{50}\right)$ was larger in the EC than in the CC $(10.3 \mathrm{~mm}$ vs. $6.0 \mathrm{~mm}$, 279 respectively).

280 Although we did not detect a significant difference in periphyton abundance between

281 the two catchments, the average quantity of periphyton was higher in the EC than in the 282 CC (Table 1). 
286 A total of nine orders, 52 families, 75 genera, 111 species, and 3,311 individuals of

287 aquatic insects were collected during our surber-net samplings.

288 The number of species was higher in the EC than in the CC in May, June, November 289 and April (Fig. 5). The Simpson's diversity index was relatively higher in the EC than 290 in the CC in all sampling months (Fig. 5). In terms of aquatic insects classified by life 291 form type, the abundance of burrowers was significantly lower in the EC than in the

292 CC, whereas the abundance of clingers was significantly higher in the EC (Table 2 and

293 Fig. 6). In terms of insects classified by functional feeding group, the abundance of

294 collector-gatherers was significantly lower in the EC than in the CC, whereas the

295 abundance of filterers was significantly higher in the EC (Table 2 and Fig. 6). The

296 abundance of shredders was significantly different among sampling months in the EC

297 and CC (Table 2 and Fig. 6). Overall samples of all months in the EC contained more

298 species of Ephemeroptera and Trichoptera than those in the CC (Table 3). The

299 proportion of the five most dominant species was lower in the EC (38.7\%) than in the

300 CC (43.9\%) (Table 4).

301

302 Discussion

303

304 Although the plant community structure at the EC and CC was very similar at the start

305 of deer exclusion in the EC (Sakaguchi et al. 2008), diverse and abundant understory

306 vegetation has recovered in the EC, whereas the forest floor has remained nearly bare

307 outside the exclosure, including the CC (Table 1, Fig. 2). The unpreferred plant species

308 for deer were commonly distributed both in the EC and CC, and the abundances of such 
309 plant species were relatively higher in the $\mathrm{CC}$ than in the EC (S1 in the ESM). These

310 results suggest that the great differences in coverage and species richness of understory

311 vegetation between the EC and CC were caused by excessive deer browsing.

312 Forest floor cover, such as understory vegetation and litter, protects the soil

313 infiltration capacity against raindrop impact (Onda and Yukawa 1994; Gomi et al. 2008)

314 and prevents overland flow from discharging (Sidle et al. 2007; Gomi et al. 2008). In

315 this study, lush understory vegetation in the EC buffered the runoff of overland flow,

316 whereas overland flow hydrographs in the CC exhibited large peaks after intermissive

317 or one-peak rainfall events (Fig. 3). The total runoff of overland flow during all three

318 types of rainfall events was lower in the EC than in the CC (Fig. 3). Because understory

319 vegetation is a good predictor of soil erosion potential (e.g., Lyon and Sagers 1998;

320 Wear et al. 1998; Heartsill-Scalley and Aide 2003), these results suggest that lush

321 understory vegetation prevents sediment runoff and soil erosion by recharging soil

322 infiltration capacity and consequently reducing overland flow. Although current

323 velocity did not differ significantly between the EC and $\mathrm{CC}$, the proportion of fine

324 sediment was significantly lower in the EC (Table 1), and the grain size of particles was

325 biased to small in the CC in comparison with that the EC (Fig. 4). These findings

326 suggest that soil erosion on the denuded slope caused increased sedimentation of fine

327 particles such as sand. In terms of the turbidity index, the abundance of periphyton was

328 higher in the EC than in the CC (Table 1). Increases in light intensity are well known to

329 cause increases in the quantity of periphyton (e.g., Hill and Harvey 1990; Wootton and

330 Power 1993). The higher growth rate of periphyton in the EC can be attributed to less

331 inflow of turbid water containing suspended sediment and to increases in light intensity

332 in the stream water (Yamada and Nakamura 2002), because of no difference in light 
333 condition (Table 1). These results suggest that the diffused fine sediment and lower

334 abundance of periphyton in the CC resulted from active sediment runoff via soil erosion

335 caused by excessive deer browsing of understory vegetation.

336 Differences in fluvial environments caused by presence or absence of deer browsing

337 are expected to alter aquatic insect assemblages. Deposited sediment is considered a

338 good quantifiable stressor for examining the functional responses of aquatic insects

339 (Waters 1995). Several studies have demonstrated the effects of fine particles that fill

340 the interstices of substrates or cover surfaces of aquatic insect habitats (e.g., Chutter

341 1969; Rabení and Minshall 1977; Minshall 1988; Wood and Armitage 1997; Zweig and

342 Rabení 2001; Rabení et al. 2005).

343 In this study, the Simpson's diversity index was greater in the EC than in the CC

344 among all sampling months (Fig. 5). Overall samplings contained more species in the

345 EC than in the CC (Table 3). The insect assemblage in the CC was characterized by the

346 dominance of sediment-burrowing ephemeropterans (e.g., Ephemera japonica

347 McLachlan and Paraleptophlebia japonica Matsumura) and dipterans (chironomid

348 midges of Orthocladiinae) (Table 4). In contrast, the assemblage in the EC was

349 dominated by crawling plecopterans (e.g., Nemoura spp. and Togoperla sp.). All of the

350 dominant sediment-burrowing taxa in the $\mathrm{CC}$ were collector-gatherers. Several studies

351 have reported decreases in species richness caused by increases in fine sediment

352 deposition (Zweig and Rabení 2001; Rabení et al. 2005). Our results also suggest that

353 fine sediment deposition of the streambed causes reductions in the diversity of aquatic

354 insect assemblages.

355 In terms of the life form types of aquatic insects, the abundance of burrowers was

356 significantly higher in the CC than in the EC (Table 2 and Fig. 6). In contrast, the 
357 abundance of clingers was significantly lower in the $\mathrm{CC}$ than in the EC, suggesting that

358 gravelly substrates were less common in the CC due to sedimentation. In general, a

359 relative tolerance to the deposition of fine sediment ( $<2 \mathrm{~mm}$ in diameter) is strongest

360 in burrowers, followed by climbers, sprawlers (crawlers), swimmers, and clingers

361 (Rabení et al. 2005). The high abundance of burrowers and the low abundance of

362 clingers in the CC corresponded to the dominance of sandy sedimental environments

363 (Table 1 and Fig. 4). In contrast, the high abundances of clingers and the low abundance

364 of burrowers in the EC corresponded to the presence of gravelly sedimental

365 environments (Table 1 and Fig. 4).

366 In terms of the functional feeding groups of aquatic insects, the abundance of

367 collector-gatherers was significantly higher in the $\mathrm{CC}$ than in the EC, whereas that of

368 filterers was significantly smaller in the CC (Table 2 and Fig. 6). In general, a relative

369 tolerance to the deposition of fine sediment is strongest in shredders, followed by

370 collector-gatherers, predators, grazers, and filterers (Rabení et al. 2005). Our results

371 suggest that the high abundance of collector-gatherers and the low abundance of

372 filterers in the $\mathrm{CC}$ corresponded to increased fine particles deposition supplied from

373 terrestrial slopes and increased overland flow.

374 In conclusion, our comparisons of aquatic insect assemblages and stream

375 environments at sites inside and outside of a deer exclosure indicate that excessive deer

376 browsing of understory vegetation causes increased overland flow and sandy

377 sedimentation of the streambed, consequently altering aquatic insect assemblages. This

378 indirect effect of deer on aquatic insects shows unexpectedly extensive effects of deer as

379 an ecosystem engineer. Deer can alter not only a terrestrial ecosystem which they

380 belong to, but also stream assemblages outside their original ecosystem. 


\section{Acknowledgements}

383

384 We thank Dr. Yasuhiro Takemon for helping with aquatic insect identification, Dr.

385 Hideaki Miyashita for helping with periphyton chlorophyll measurements, and Dr.

386 Mayumi Yoshimura for providing advice concerning the methods. We also thank the

387 staff of the Ashiu Forest Research Station for enabling us to conduct this research.

388 Invaluable advice for this manuscript was provided by Dr. Keitaro Fukushima, Dr.

389 Atsushi Kawakita, Dr. Yasuo Mukai, Mr. Shota Sakaguchi, Dr. Atsushi Takayanagi, the

390 anonymous two reviewers, and the editor. Considerable field assistance was provided

391 by several academic colleagues. A portion of this study was funded by the ProNatura

392 Fund.

393

\section{References}

Akashi N, Nakashizuka T (1999) Effects of bark-stripping by sika deer (Cervus nippon) on population dynamics of a mixed forest in Japan. For Ecol Manage 113:75-82

Allan JD (1982) The effects of reduction in trout density on the invertebrate community of a mountain stream. Ecology 63:1444-1455

Asada M, Ochiai K (1996) Food habits of sika deer on the Boso Peninsula, central

$401 \quad$ Japan. Ecol Res 11:89-95

402 Casabon C, Pothier D (2008) Impacts of deer browsing on plant communities in cutover sites on Anticosti Island. Ecoscience 15:389-397

404 Christopher TR, Minshall GW (1986) Effects of disturbance frequency on stream bethic 
405 community structure in relation to canopy cover and season. J N Am Benthol Soc

$406 \quad 5: 237-248$

407 Chutter FM (1969) The effects of silt and sand on the invertebrate fauna of streams and

408 rivers. Hydrobiologia 34:57-76

409 Côté SD, Rooney TP, Trembley J-P, Dussault C, Waller DM (2004) Ecological impacts

410 of deer overabundance. Annu Rev Ecol Evol Syst 35:113-147

411 Covich DR, Palmer MA, Crowl TA (1999) The role of benthic invertebrate species in

412 fresh water ecosystems. Bioscience 49:119-127

413 Cummins KW, Merritt RW, Berg MB (2008) Ecology and distribution of aquatic

414 insects. In: Merritt RW, Cummins KW, Berg MB (eds) An introduction to the

415 aquatic insects of North America. Kendall/Hunt Publishing Company, Iowa, pp 105-

$416 \quad 122$

417 Fukushima K, Tokuchi N (2008) The influences of deer overbrowsing on nutrient

418 cycling in forest ecosystems: preliminary study of streamwater chemistry. For Res

419 Kyoto 77:77-87 (in Japanese)

420 Fuller RJ, Gill RMA (2001) Ecological impacts of increasing numbers of deer in British

$421 \quad$ woodland. Forestry 74:193-199

422 Furusawa H, Miyanishi H, Kaneko S, Hino T (2003) Movement of soil and litter on the

423 floor of a temperate mixed forest with an impoverished understory grazed by deer

424 (Cervus nippon centralis Temminck). J Jpn For Soc 85:318-325 (in Japanese)

425 Gill RMA, Beardall V (2001) The impact of deer on woodlands: the effects of browsing

426 and seed dispersal on vegetation structure and composition. Forestry 74:209-218

427 Gomi T, Sidle RC, Ueno M, Miyata S, Kosugi K (2008) Characteristics of overland

428 flow generation on steep forested hillslopes of central Japan. J Hydrol 361:275-290. 
429 Heartsill-Scalley T, Aide TM (2003) Riparian vegetation and stream condition in a

$430 \quad$ tropical agriculture - secondary forest mosaic. Ecol Appl 13:225-234

431 Heino J, Muotka T, Mykra H, Paavola R, Hamalainen H, Koskenniemi E (2003)

432 Defining macroinvertebrate assemblage types of headwater streams: implications for 433 bioassessment and conservation. Ecol Appl 13:842-852

434 Hill WR, Harvey BC (1990) Periphyton responses to higher trophic levels and light in a 435 shaded stream. Can J Fish Aquat Sci 47:2307-2314

436 Horsley SB, Stout SL, deCalesta DS (2003) White-tailed deer impact on the vegetation 437 dynamics of a northern hardwood forest. Ecol Appl 13:98-118

438 Horton RE (1945) Erosional development of streams and their drainage basins:

439 hydrophysical approach to quantitative morphology. Bull Geol Soc Am 56:275-370

440 Jeffrey SW, Humphrey GF (1975) New spectrophotometric equations for determining

441 chlorophyll a, b, c1 and c2 in higher plants, algae, and natural phytoplankton.

$442 \quad$ Biochem Physiol Pflanz 167:191-194

443 Kato M, Okuyama Y (2004) Changes in the biodiversity of a deciduous forest 444 ecosystem caused by an increase in the sika deer population at Ashiu, Japan. Contr $445 \quad$ Biol Lab Kyoto Univ 29:237-448

446 Kawai T, Tanida K (2005) Aquatic insects of Japan: manual with keys and illustrations.

447 Tokai University Press, Kanagawa (in Japanese)

448 Lyon J, Sagers CL (1998) Structure of herbaceous plant assemblages in a forested 449 riparian landscape. Plant Ecol 138:1-16

450 Matthaei CD, Weller F, Kelly DW, Townsend CR (2006) Impacts of fine sediment 451 addition to tussock, pasture, and deer farming streams in New Zealand. Freshwater $452 \quad$ Biol 51:2154-2172 
453 Merritt RW, Cummins KW, Berg MB (2008) An introduction to the aquatic insects of

$454 \quad$ North America. 4th edn. Kendall/Hunt Publishing Company, Iowa

Minshall GW (1988) Stream ecosystem theory: a global perspective. J N Am Benthol Soc 7:263-288

Miura S, Tokida K (2008) Management strategy of sika deer based on sensitivity analysis. In: McCullough DR, Kaji K, Takatsuki S (eds) Sika deer: biology and management of native and introduced populations. Springer, Tokyo, pp 453-472

Miyashita T, Suzuki M, Ando D, Fujita G, Ochiai K, Asada M (2008) Forest edge creates small-scale variation in reproductive rate of sika deer. Popul Ecol 50:111120

Nomiya H, Suzuki W, Kanazashi T, Shibata M, Tanaka H, Nakashizuka T (2003) The response of forest floor vegetation and tree regeneration to deer exclusion and disturbance in a riparian deciduous forest, central Japan. Plant Ecol 164:263-276

Onda Y, Yukawa N (1994) The influence of understories and litter layer on the infiltration of forested hillslope. In: Ohta T (ed) Proceedings of international symposium on forest hydrology. University of Tokyo, Japan, pp 107-114

Rabení CF, Minshall GW (1977) Factors affecting the micro-distribution of stream benthic insects. Oikos 29:33-43

Rabení CF, Doicy KE, Zweig LD (2005) Stream invertebrate community functional responses to deposited sediment. Aquat Sci 67:395-402

Rader RB, Ward JV (1990) Mayfly growth and population density in constant and variable temperature regimes. Great Basin Nat 50:97-106 
477 Richardson JS, Danehy RJ (2007) A synthesis of the ecology of headwater streams and 478 their riparian zones in temperate forests. For Sci 53:131-147

Robinson CT, Minshall GW (1986) Effects of disturbance frequency on stream benthic community structure in relation to canopy cover and season. J N Am Benthol Soc $5: 237-248$

Rooney TP (2001) Deer impacts on forest ecosystem: a North American perspective. Forestry 74:201-208

Sakaguchi S, Fujiki D, Inoue M, Takayanagi A (2008) Plant species diversity and community structure of old-growth beech forest in Kamitani, Ashiu, Kyoto community structure and endangered plant species detected by gradsect networks -. For Res Kyoto 77:43-61 (in Japanese)

Sidle RC, Hirano T, Gomi T, Terajima T (2007) Hortonian overland flow from Japanese forest plantations - an aberration, the real thing, or something in between? Hydrol Process 21:3237-3247

Takatsuki S, Gorai T (1994) Effects of sika deer on the regeneration of a Fagus crenata forest on Kinkazan Island, northern Japan. Ecol Res 9:115-120

493 Takemon Y (2005) Life-type concept and functional feeding groups of benthos 494 communities as indicators of lotic ecosystem conditions. Jpn J Ecol 55:189-197 (in 495 Japanese)

496 Tanaka Y, Takatsuki S, Takayanagi A (2008) Decline of Sasa palmata community by 497 grazing of Sika deer (Cervus nippon) at Ashiu Research Forest Station. For Res $498 \quad$ Kyoto 77:13-23 (in Japanese)

499 Vannote RL, Sweeny BW (1980) Geographic analysis of thermal equilibria: a 500 conceptual model for evaluating the effect of natural and modified thermal regimes 
Wakahara T, Ishikawa Y, Shiraki K, Toda H, Miya T, Kataoka F, Suzuki M, Uchiyama Y (2008) Seasonal changes in the amount of litter layer and soil erosion in the forest floor: an impoverished understory by deer impact at Doudaira, Tanzawa Mountains. J Jpn For Soc 90:378-385 (in Japanese)

Waters TF (1995) Sediment in streams: sources, biological effects and control. Am Fish Soc, Benthesda Maryland, USA

Wear DN, Turner MG, Naiman RJ (1998) Land cover along an urban-rural gradient: implications for water quality. Ecol Appl 8:619-630.

510 Wood PJ, Armitage PD (1997) Biological effects of fine sediment in the lotic

511 environment. Environ Manage 21:203-217

512 Wootton JT, Power ME (1993) Productivity, consumers, and the structure of a river food chain. Proc Natl Acad Sci USA 90:1384-1387

514 Yamada H, Nakamura F (2002) Effect of fine sediment deposition and channel works

515 on periphyton biomass in the Makomanai River, northern Japan. Riv Res Appl

$516 \quad 18: 481-493$

517 Yamamura K (1999) Transformation using $(x+0.5)$ to stabilize the variance of 518 populations. Res Popul Ecol 41:229-234

519 Yanagi Y, Takada M, Miyashita T (2008) Changes in the physical properties of forest 520 soils in the Boso Peninsula due to sika deer revealed by surveys and field experiment. $521 \quad$ Jpn J Conserv Ecol 13:65-74 (in Japanese)

522 Yokoyama S \& Shibata E (1998) The effects of sika-deer browsing on the biomass and 523 morphology of a dwarf bamboo, Sasa nipponica, in Mt. Ohdaigahara, central Japan. $524 \quad$ For Ecol Manage 103:49-56 
525 Yoshimura M (2007) Comparison of stream benthic invertebrate assemblages among

526 forest types in the temperate region of Japan. Biodivers Conserv 16:2137-2148

527 Zweig LD, Rabení CF (2001) Biomonitoring for deposited sediment using benthic

528 invertebrates: a test on 4 Missouri streams. J N Am Benthol Soc 20:643-657 
Table 1 Comparisons of average values of eleven environmental characteristics between the exclosure and control catchments. Differences between the catchments in coverage of understory vegetaion, quantitiy of litter, water temperature, water depth, current velocity, proportion of fine sediment, relative solar radiation and periphyton abundance were tested using $t$ test. Values are means \pm standard deviation.

\begin{tabular}{|c|c|c|}
\hline & Exclosure catchment & Control catchment \\
\hline Catchment area (ha) & 1.15 & 1.66 \\
\hline Deer invasion & Deer excluded & Invasion frequent \\
\hline Forest type & Deciduous forest & Deciduous forest \\
\hline Coverage of understory vegetation (\%) & $45.40 \pm 29.36^{* *}$ & $18.20 \pm 12.60 * *$ \\
\hline Quantity of litter (g): August & $79.75 \pm 24.55$ & $47.54 \pm 23.51$ \\
\hline : November & $74.25 \pm 35.28$ & $124.25 \pm 25.90$ \\
\hline Water temperature $\left({ }^{\circ} \mathrm{C}\right)$ & $14.70 \pm 4.04$ & $14.66 \pm 4.05$ \\
\hline Water depth $(\mathrm{cm})$ & $2.35 \pm 1.76^{* *}$ & $3.25 \pm 1.65^{* *}$ \\
\hline Current velocity $\left(\mathrm{cm} \mathrm{s}^{-1}\right)$ & $4.34 \pm 2.72$ & $4.82 \pm 2.75$ \\
\hline Proportion of fine sediment $(\%)$ & $18.10 \pm 7.86^{* *}$ & $36.99 \pm 9.37 * *$ \\
\hline Relative solar radiation (\%): August & $19.31 \pm 6.88^{*}$ & $12.58 \pm 2.2^{*}$ \\
\hline : November & $38.01 \pm 6.82$ & $40.70 \pm 7.67$ \\
\hline Periphyton abundance (mg chl. $a 4 \mathrm{~cm}^{-2}$ ) & $32.09 \pm 19.76$ & $7.45 \pm 2.52$ \\
\hline
\end{tabular}


Table 2 Results of ANOVAs testing for effects of site and month on abundances of each aquatic insect group.

\begin{tabular}{lrrllll}
\hline & \multicolumn{2}{c}{ Site } & \multicolumn{2}{c}{ Month } & \multicolumn{2}{c}{ Site $\times$ month } \\
\cline { 2 - 7 } & \multicolumn{1}{c}{$F$} & $P$ & $F$ & $P$ & $F$ & \multicolumn{1}{l}{$P$} \\
\hline Burrowers & 14.481 & $\mathbf{< . 0 0 1}$ & 1.864 & 0.097 & 1.456 & 0.206 \\
Clingers & 8.869 & $\mathbf{0 . 0 0 5}$ & 0.585 & 0.765 & 0.843 & 0.558 \\
Crawlers & 3.522 & 0.068 & 1.413 & 0.222 & 2.128 & 0.058 \\
Swimmers & 0.015 & 0.902 & 1.779 & 0.113 & 1.264 & 0.288 \\
\hline Collector-gatherers & 12.033 & $\mathbf{0 . 0 0 1}$ & 2.026 & 0.071 & 1.615 & 0.154 \\
Filterers & 6.288 & $\mathbf{0 . 0 1 6}$ & 0.668 & 0.698 & 0.809 & 0.584 \\
Grazers & 0.014 & 0.906 & 0.841 & 0.559 & 1.849 & 0.099 \\
Predators & 2.494 & 0.121 & 1.603 & 0.157 & 1.192 & 0.325 \\
Shredders & 3.265 & 0.077 & 3.535 & $\mathbf{0 . 0 0 4}$ & 1.556 & 0.172 \\
\hline
\end{tabular}


Table 3 Richness and abundance of aquatic insect of overall samples in all months in each order in each catchment.

\begin{tabular}{lrrrr}
\hline & \multicolumn{2}{c}{ Exclosure catchment } & \multicolumn{2}{c}{ Control catchment } \\
\hline Order & Taxa & Indv. & Taxa & Indv. \\
\hline Ephemeroptera & 17 & 339 & 12 & 610 \\
Odonata & 7 & 13 & 8 & 39 \\
Plecoptera & 14 & 462 & 11 & 464 \\
Coleoptera & 5 & 77 & 6 & 49 \\
Diptera & 25 & 239 & 25 & 549 \\
Trichoptera & 19 & 206 & 14 & 231 \\
Others & 5 & 16 & 2 & 17 \\
\hline Total & 92 & 1,352 & 75 & 1,959 \\
\hline
\end{tabular}


Table 4 Dominant species of aquatic insect assemblages of overall samples in all months in each catchment. E, P and D in order row correspond to Ephemeroptera, Plecoptera and Diptera respectively.

\begin{tabular}{lrrlrrr}
\hline Rank Site & Order Life form type & Feeding group & \multicolumn{2}{c}{ Indv. Proportion } \\
\hline \multicolumn{2}{l}{ Exclosure catchment } & & & & & \\
1 & Ephemera japonica & E & Burrower & Collector-gatherer & 129 & $9.5 \%$ \\
2 & Nemoura spp. & P & Crawler & Shredder & 123 & $9.1 \%$ \\
3 & Togoperla sp. & P & Crawler & Predator & 110 & $8.1 \%$ \\
4 & Caroperla sp. & P & Crawler & Predator & 82 & $6.0 \%$ \\
5 & Paraleptophlebia japonica & E & Burrower & Collector-gatherer & 81 & $6.0 \%$ \\
& & & & & Total & $38.7 \%$ \\
& Control catchment & & & & & \\
1 & Ephemera japonica & E & Burrower & Collector-gatherer & 298 & $15.2 \%$ \\
2 & Caroperla sp. & P & Crawler & Predator & 156 & $8.0 \%$ \\
3 & Paraleptophlebia japonica & E & Burrower & Collector-gatherer & 149 & $7.6 \%$ \\
4 & Nemoura spp. & P & Crawler & Shredder & 138 & $7.0 \%$ \\
5 & Orthocladiinae spp. & D & Burrower & Collector-gatherer & 120 & $6.1 \%$ \\
& & & & & Total & $43.9 \%$ \\
\hline
\end{tabular}




\section{$530 \quad$ Figure Legends}

531 Fig. 1 The study site in the Ashiu Forest, Kyoto Prefecture, Japan.

532 Fig. 2 Landscapes at (a) the exclosure catchment (EC) and (b) the control catchment

533 (CC) on 28 June 2008.

534 Fig. 3 Representative overland flow hydrographs ( $\mathrm{mm} / 5 \mathrm{~min})$ at the exclosure and

535 control catchments.

536 Fig. 4 Grain size distribution of stream substrate at the exclosure and control

537 catchments. Error bars indicate \pm standard deviation.

538 Fig. 5 Number of species and Simpson's diversity index in each sampling month at the

539 exclosure and control catchments. Error bars indicate \pm standard deviation.

540 Fig. 6 Abundances of four life form types and five functional feeding groups of aquatic

541 insects in each sampling month at the exclosure and control catchments. Error bars

542 indicate \pm standard deviation. 
Fig. 1

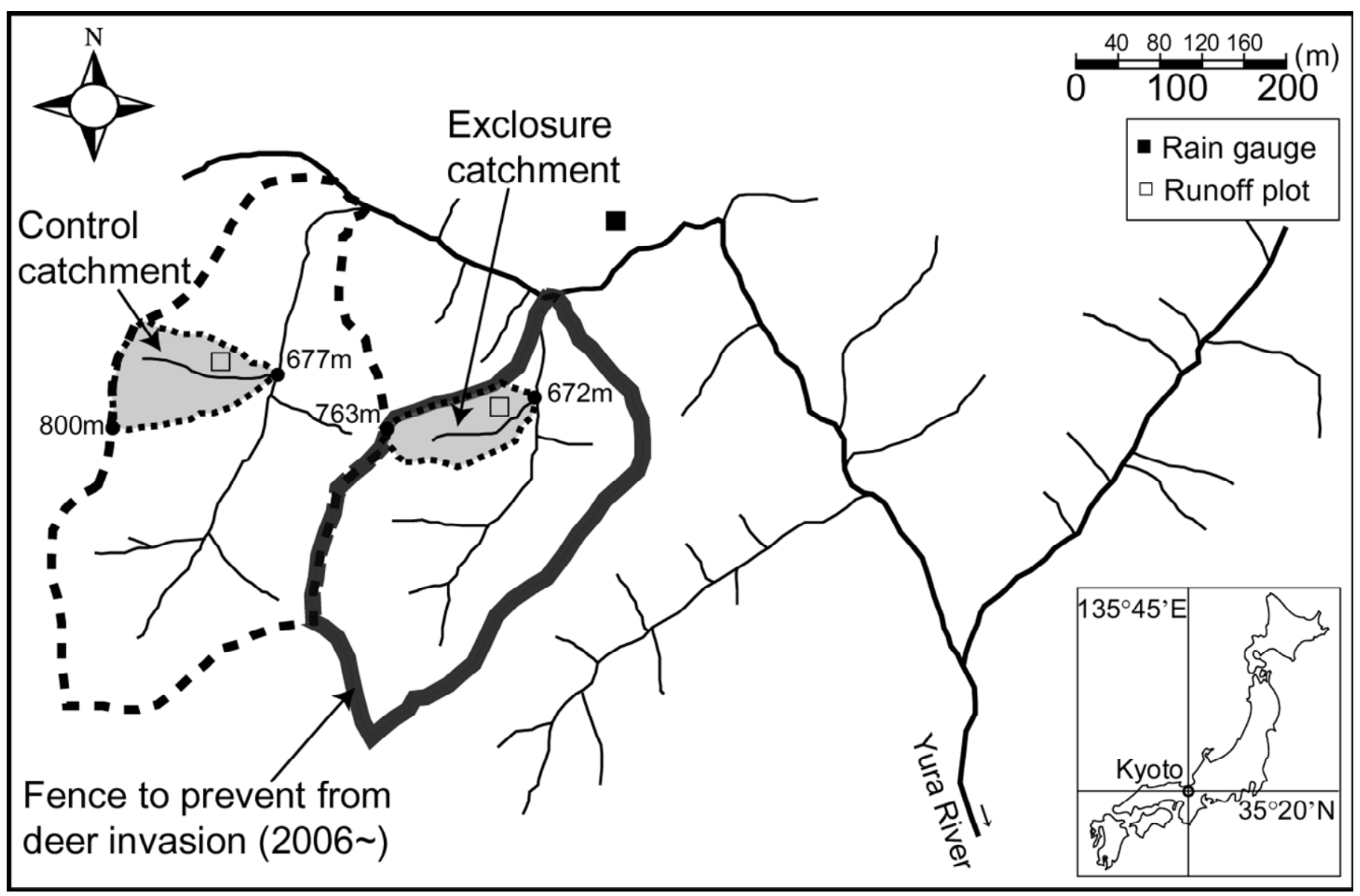




\section{(a) Exclosure catchment (EC)}

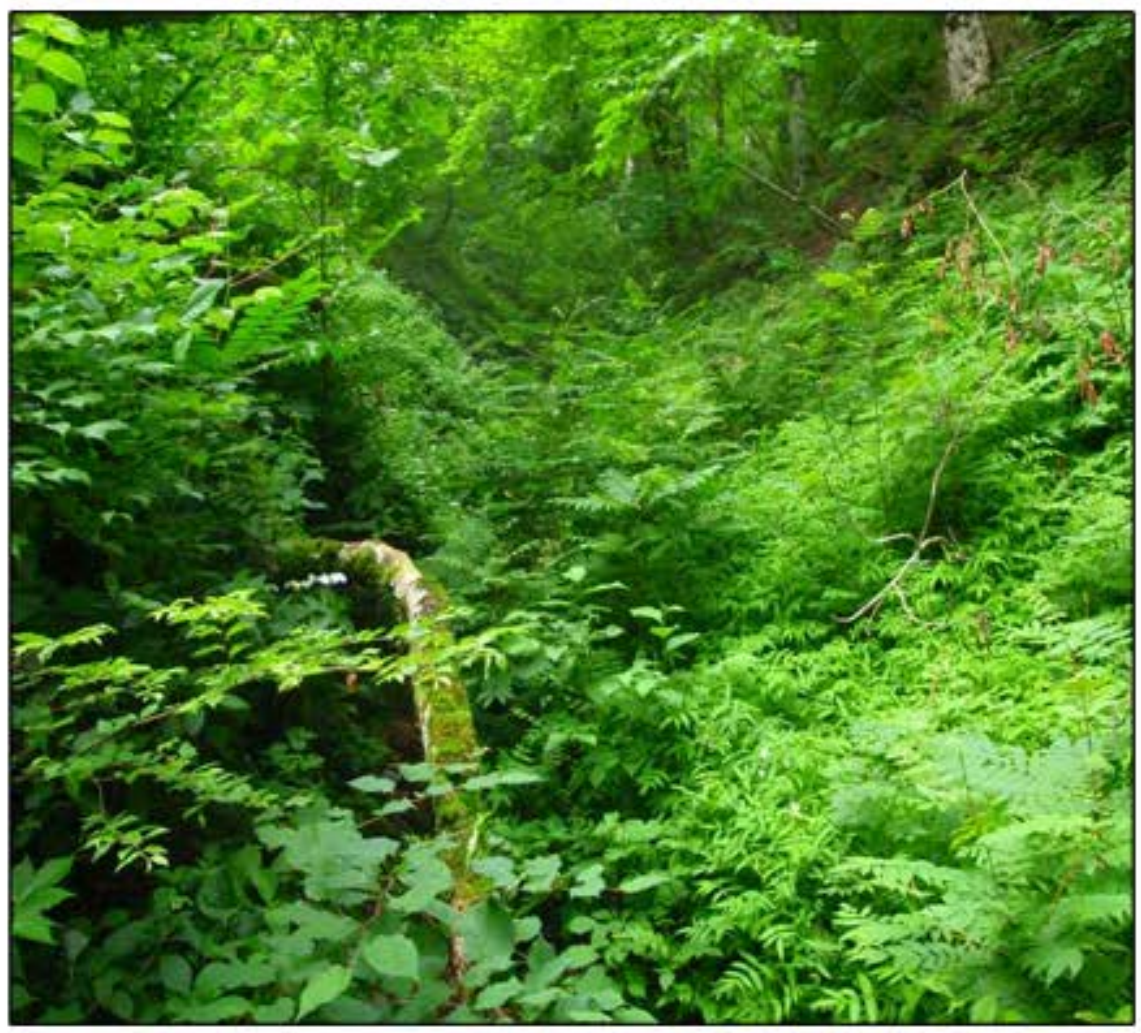

\section{(b) Control catchment (CC)}

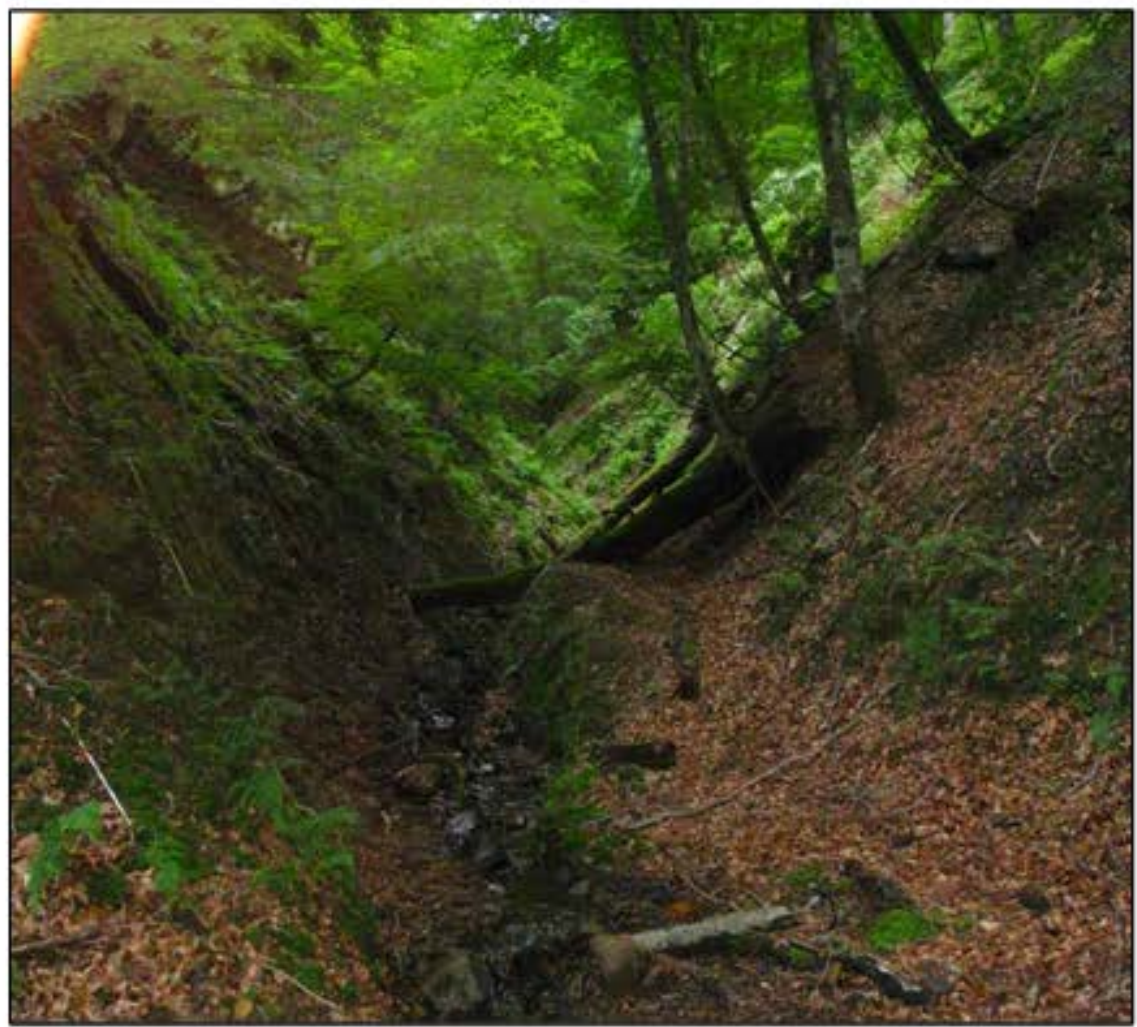


Fig. 3

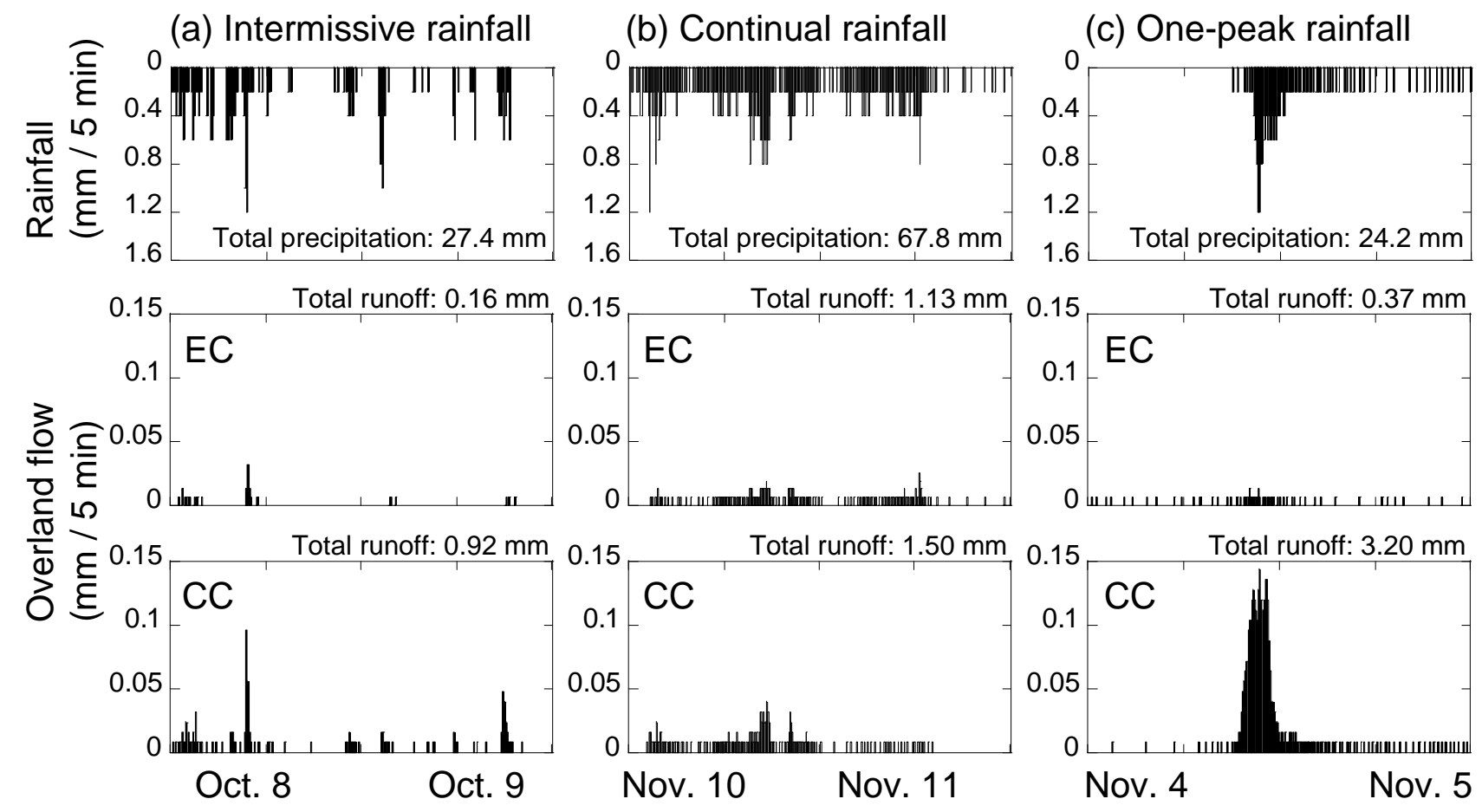


Fig. 4

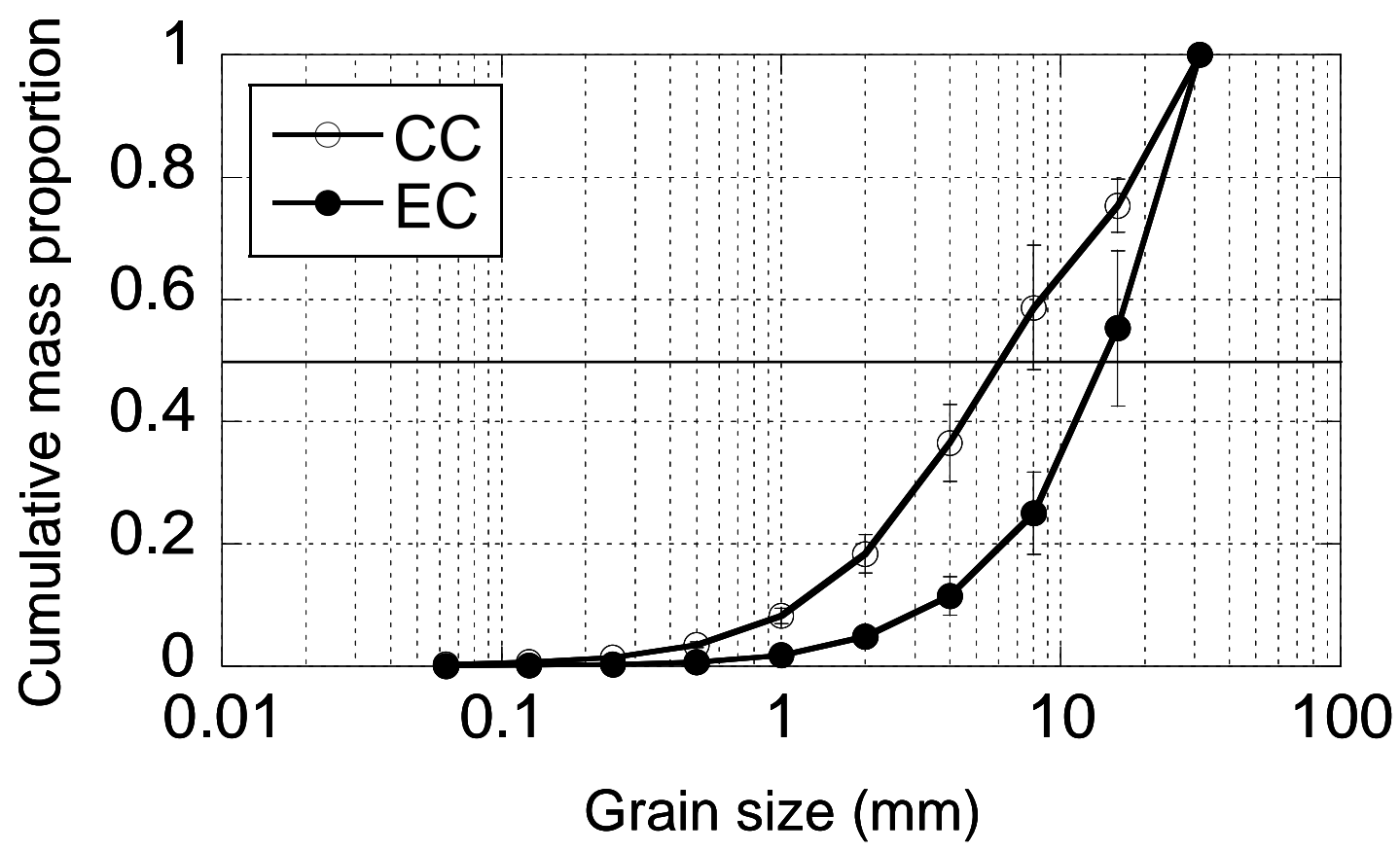


Fig. 5
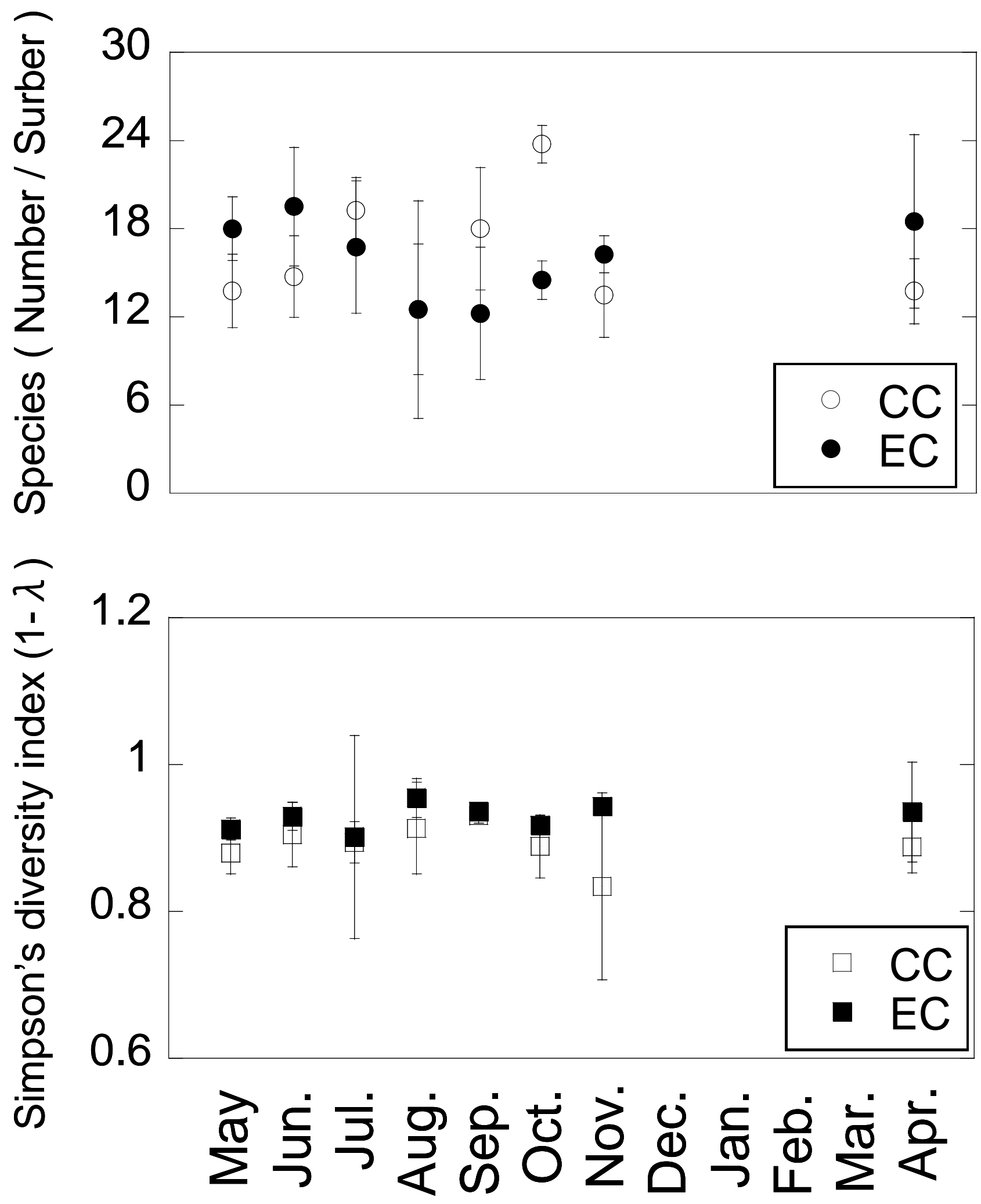
Fig. 6

Life form type

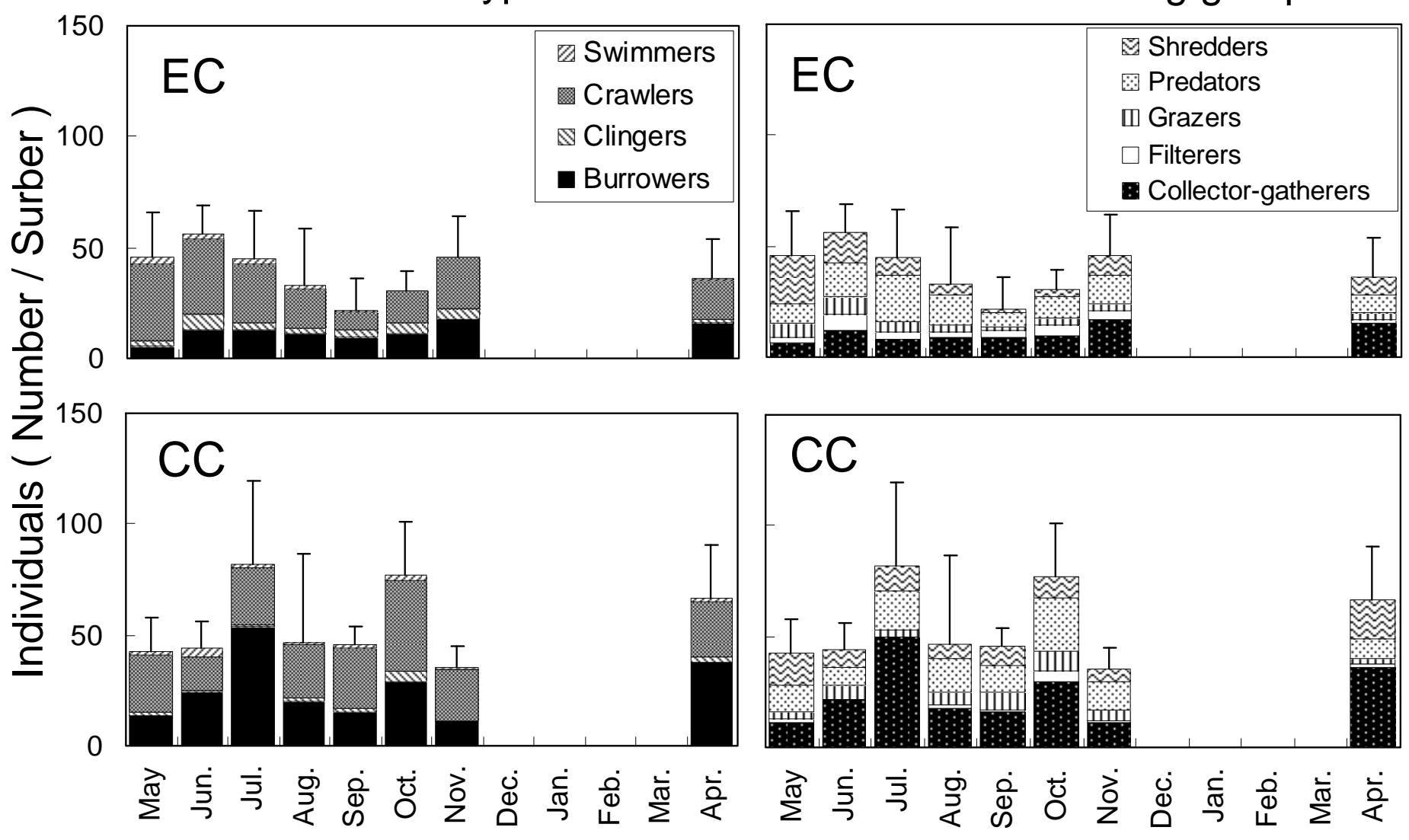

\section{Functional feeding group}


Title: Indirect effects of excessive deer browsing through understory vegetation on stream insect assemblages.

Authors: Masaru Sakai, Yosihiro Natuhara, Ayumi Imanishi, Kensuke Imai, Makoto Kato

ESM_S1 Coverage of understory plant species at the exclosure catchment and control catchment in the belt transect survey.

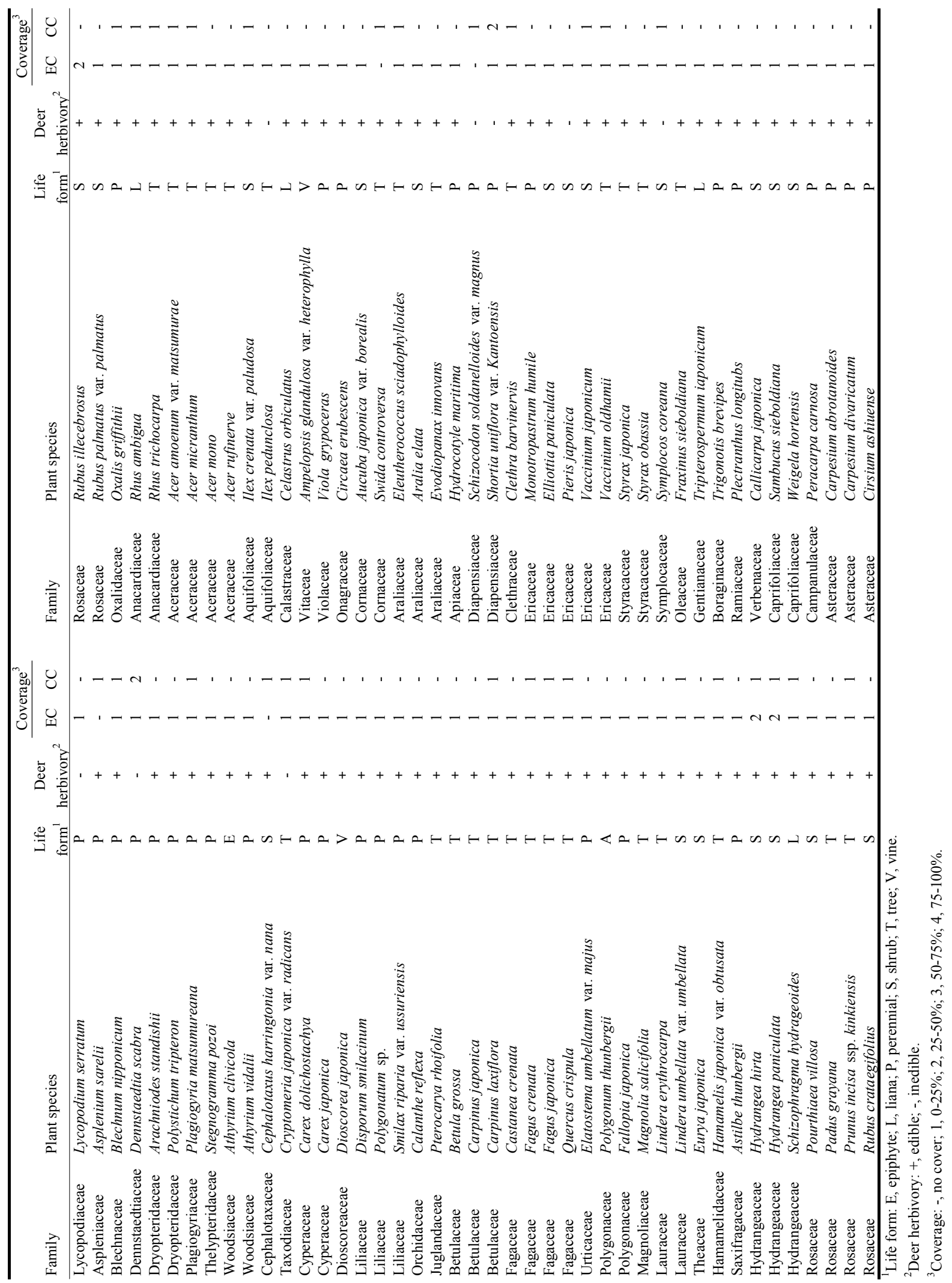


Title: Indirect effects of excessive deer browsing through understory vegetation on stream insect assemblages.

Authors: Masaru Sakai, Yosihiro Natuhara, Ayumi Imanishi, Kensuke Imai, Makoto Kato

ESM_S2 List of families and genera of aquatic insects of overall samples in all months recorded at the exclosure catchment and control catchment.

\begin{tabular}{|c|c|c|c|c|c|c|c|}
\hline Order & Family or genus & $\mathrm{EC}$ & $\mathrm{CC}$ & Order & Family or genus & $\mathrm{EC}$ & $\mathrm{CC}$ \\
\hline \multirow[t]{14}{*}{ Ephemeropter } & Ameletus & 2 & 1 & Diptera & Ablabesmyia & 0 & 1 \\
\hline & Baetiella & 1 & 2 & & Antocha & 2 & 0 \\
\hline & Baetis & 39 & 44 & & Athericidae & 2 & 0 \\
\hline & Bleptus & 3 & 0 & & Ceratopogonidae & 10 & 48 \\
\hline & Cinygmula & 7 & 3 & & Conchapelopia & 27 & 13 \\
\hline & Dipteromimus & 5 & 2 & & Diamesinae & 22 & 64 \\
\hline & Ecdyonurus & 64 & 108 & & Dicranota & 6 & 9 \\
\hline & Epeorus & 2 & 1 & & Dixa & 3 & 5 \\
\hline & Ephemera & 129 & 298 & & Epoicocladius & 50 & 80 \\
\hline & Ephemerella & 1 & 1 & & Haxatoma & 2 & 0 \\
\hline & Heptagenia & 2 & 0 & & Limnophila & 21 & 14 \\
\hline & Paraleptophlebia & 81 & 149 & & Limoniinae & 2 & 1 \\
\hline & Procloeon & 1 & 0 & & Neobrillia & 4 & 2 \\
\hline & Rhithrogena & 2 & 1 & & Orthocladiinae & 18 & 120 \\
\hline \multirow[t]{9}{*}{ Odonata } & Aeshna & 1 & 0 & & Pedicia & 9 & 4 \\
\hline & Anotogaster & 1 & 11 & & Pentaneura & 2 & 3 \\
\hline & Davidius & 4 & 8 & & Pilaria & 0 & 1 \\
\hline & Epiophlebia & 0 & 1 & & Simuliidae & 0 & 1 \\
\hline & Gomphus & 0 & 1 & & Suragina & 3 & 1 \\
\hline & Lanthus & 1 & 4 & & Tabanidae & 21 & 58 \\
\hline & Mnais & 1 & 5 & & Tanypodinae & 6 & 6 \\
\hline & Planaeschna & 3 & 8 & & Tanytarsus & 11 & 116 \\
\hline & Polycanthagyna & 2 & 0 & & Tipula & 17 & 5 \\
\hline \multirow[t]{13}{*}{ Plecoptera } & Amphinemura & 65 & 29 & & Tvetenia & 1 & 0 \\
\hline & Caroperla & 82 & 156 & Trichoptera & Agapetus & 8 & 6 \\
\hline & Haploperla & 31 & 13 & & Apatania & 0 & 1 \\
\hline & Isoperla & 1 & 3 & & Arctopsyche & 2 & 0 \\
\hline & Kiotina & 1 & 0 & & Brachycentrus & 3 & 0 \\
\hline & Leuctridae & 22 & 18 & & Diplectrona & 2 & 0 \\
\hline & Nemocapnia & 1 & 0 & & Dolophilodes & 30 & 22 \\
\hline & Nemoura & 123 & 138 & & Glossosoma & 1 & 0 \\
\hline & Niponiella & 13 & 47 & & Goera & 3 & 0 \\
\hline & Protonemura & 10 & 0 & & Hydropsyche & 79 & 25 \\
\hline & Pseudomegarcys & 0 & 1 & & Lepidosotma & 30 & 44 \\
\hline & Sweltsa & 3 & 2 & & Leptocerus & 0 & 2 \\
\hline & Togoperla & 110 & 56 & & Micrasema & 2 & 0 \\
\hline \multirow[t]{3}{*}{ Megaloptera } & Parachauliodes & 12 & 9 & & Perissoneura & 14 & 45 \\
\hline & Protohermes & 1 & 0 & & Plectrocnemia & 0 & 1 \\
\hline & Sialis & 1 & 8 & & Psilotreta & 3 & 63 \\
\hline Hemiptera & Mesovelia & 1 & 0 & & Rhyacophila & 25 & 21 \\
\hline \multirow[t]{6}{*}{ Coleoptera } & Dryopomorphus & 2 & 0 & & Setodes & 2 & 0 \\
\hline & Eubrianax & 14 & 13 & & Wormaldia & 2 & 1 \\
\hline & Hydrocyphon & 0 & 1 & & & & \\
\hline & Paralichas & 59 & 32 & & & & \\
\hline & Pseudamophihs & 1 & 1 & & & & \\
\hline & Sacodes & 2 & 1 & & & & \\
\hline
\end{tabular}

